\title{
Bridging the Gap: National Human Rights Institutions and the Inter-American Human Rights System
}

\author{
Tom Pegram with Nataly Herrera*
}

\section{Introduction}

As the focus turns towards the challenge of human rights implementation, increasing attention is being paid to how the Inter-American Human Rights System (IAHRS) actually informs human rights politics and practice in domestic jurisdictions. In this task, national human rights institutions (NHRIs) in Latin America, most commonly Human Rights Commissions or Ombudsmen (Comisiones Nacionales de los Derechos Humanos and Defensorías del Pueblo), have emerged as potentially important intermediary actors for both the Inter-American Commission on Human Rights (IACHR) and the Inter-American Court of Human Rights (IACtHR), serving as links in the transmission and implementation of international human rights norms and rulings. NHRIs occupy a distinctive position within state structures. Formally independent, but state funded, they have been seized upon as IAHRS 'implementation partners' at the local level (Open Justice 2013).

Notwithstanding their potential role in advancing IAHRS objectives, the relationship between the IAHRS and NHRIs has received little scholarly attention. ${ }^{1}$ This chapter seeks to address this deficit. Debate on the potential for multiplying compliance constituencies to scale up the impact of the IAHRS at the local level is gathering pace, partly driven by more reflexive appraisal of the limitations of a supranational system which suffers from chronic resource constraints and lack of enforcement authority. Debate surrounding strategies aimed at enhancing implementation, such as conventionality control, have understandably devoted attention to apex political and judicial bodies. NHRIs have been largely peripheral to this debate. However, as this chapter documents, although lacking in enforcement authority themselves, national institutions can play an important role in mobilising domestic human rights politics, drawing on a range of protective and promotional powers.

\footnotetext{
* This chapter was written by Tom Pegram, Lecturer in Global Governance and Deputy Director of the Global Governance Institute at University College London, with Nataly Herrera, an independent human rights consultant. The authors are extremely grateful to all those who gave generously of their time during the course of this research project. We wish to thank in particular Fernando Castañeda for his valuable insights, as well as Par Engstrom, Peter Low, and Oscar Parra-Vera for extremely helpful comments. All errors remain ours alone. ${ }^{1}$ For notable exceptions, see Aguilar and Mendez 1997; Parra Vera 2009.
} 
This chapter also contributes to debate in human rights scholarship. Progress has been made in specifying the linkages between international and domestic jurisdictions in human rights mobilisation (Risse 2013). However, the impact of human rights instruments has often been assumed to be the outcome of transgovernmental processes contained principally to engagement among political elites (Finnemore 1996). Less attention has been given to 'bottom-up' accounts of the effects of international human rights instruments (Simmons 2009: 138). This is an important analytical move given that implementation is contingent on the mobilisation efforts of diverse actors. This is especially true of contexts displaying unstable rule of law frameworks where the limits of formal pathways to compliance are likely to be particularly profound (Levitsky and Murillo 2009). In such settings, the impact of IAHRS entities may be most evident in the intermediate actions that they take to facilitate mobilisation by pro-compliance actors on the ground. Such inquiry raises important questions regarding when and why the IAHRS will seek to coordinate with NHRIs and vice versa. This chapter pursues this line of inquiry.

Complementing a substantial scholarship on the role of human rights NGOs and the IAHRS (Cavallaro and Brewer 2008), this chapter also highlights the role of a distinctive class of sub-state human rights actor located within state structures, but independent of government. Their position within state structures and the status often attached to the office makes them potentially attractive agents for transnational mobilisation by the IAHRS, in terms of tapping into domestic sites of both political influence and resources. Importantly, NHRIs can also serve as venues for facilitating domestic mobilisation efforts by third party actors within civil society. NHRIs have at different moments made important contributions to advancing human rights protection in Latin America (Pegram 2012). However, as this study highlights, it is important to also acknowledge the limitation of NHRIs. Even where robust official implementation mechanisms such as NHRIs exist, careful attention must be paid to their actual performance in order to avoid the risk of creating 'illusions of compliance' whereby formal rule-compliance substitutes for more meaningful indicators of positive change (Open Justice 2013: 16).

To document our claims, the chapter draws on an extensive body of comparative information and interview data to substantiate the relationship between NHRIs and IAHRS. The analysis surveys the experience of these institutions across Latin America, with comparative analysis 
supplemented by an in-depth case study of the pioneering work of the Peruvian Human Rights Ombudsmen in this field. The chapter begins with a discussion of NHRIs as IAHRS compliance intermediaries, with particular attention paid to their formal aptitude to assume such a function. We then highlight the formal relationship between NHRIs and the IAHRS before specifying modalities of engagement in greater detail, drawing on the experience of NHRIs throughout the region. The chapter closes with an in depth case study of the Peruvian office and an examination of what the analysis means for the future of NHRI-IAHRS relations and research on the system more generally.

\section{National human rights institutions in Latin America}

NHRIs are well-placed to serve as compliance intermediaries within the IAHRS, serving to link international human rights standards with domestic legal and political processes, institutions and actors (Carver 2000). ${ }^{2}$ NHRIs can be found in every country in Latin America, with the exception of Brazil. They are emblematic of the growing penetration of human rights structures within domestic jurisdictions throughout the Americas. ${ }^{3}$ Locating NHRIs within a transgovernmental framework highlights the importance of disaggregating the state, as well as mapping out the multiple linkages and relative power of sections of the state bureaucracy dealing with human rights (Slaughter 2004). They are widely held to constitute an essential element of a strong national human rights system, acting as a bridge between governments and civil society, linking the rights of citizens with the responsibilities of the state, and creating connections between national laws and regional and international human rights mechanisms (Smith 2006).

NHRIs can be located in theory as sitting at the intersection between vertical (direct electoral channels) and horizontal (state checks and balances) accountability domains within the state (O’Donnell 1998). In Latin America, all of these offices conform to the international standards on NHRI design, the Paris Principles, which stipulate minimum design safeguards

\footnotetext{
${ }^{2}$ The NHRI has been (loosely) defined as 'a body which is established by a Government under the constitution, or by law or decree, the functions of which are specifically designed in terms of the promotion and protection of human rights' (UN 1995: 4).

${ }^{3}$ Outside of Europe, the Americas display the highest regional concentration of NHRIs, with twenty-six of thirty-five OAS members, or seventy-five percent, having established such an institution.
} 
of independence and powers. ${ }^{4}$ They are generally mandated to proactively advise the executive and public bureaucracy on public policy, as well as make recommendations on legislative projects and promote a broad rights mandate. The Colombian office, for example, has been praised for its coordination efforts across state bodies and for the information published in its reports. ${ }^{5}$ Importantly, NHRIs receive complaints from the general public, at no cost to the complainant, and are mandated to pursue resolution of issues through engagement with the responsible public entity. This reactive power is complemented by the ability to initiate special investigations into any human rights issue at the institution's discretion. The public service orientation of the NHRI and its potential to serve as a national referent point for human rights discourse has been acknowledged by members of the IACHR. $^{6}$

NHRIs generally exercise a 'fire alarm' form of oversight over the public bureaucracy (Przeworski et al. 1999). Reflecting a core accountability role, safeguards of independence are generally robust, including no executive designation of personnel. ${ }^{7}$ Significantly, Latin American NHRIs enjoy far-reaching investigative powers, including complaint-handling powers, robust investigative prerogatives, and court referral authority (habeas corpus, amparo, habeas data and constitutional review powers). ${ }^{8}$ NHRIs are not judicial bodies and they lack legally binding authority. Compliance with its recommendation often rests on reputation and persuasive authority.

Salient to this study, many NHRIs in the region have an explicit mandate to monitor, promote and/or advise on implementation of Member States' obligations under international human rights law. ${ }^{9}$ In practice, irrespective of enabling legislation, many NHRIs have interpreted their mandates widely, seeking to define their domestic and international roles in accordance

\footnotetext{
${ }^{4}$ All NHRIs in Latin America are accredited 'A status' by the UN-affiliated International Coordinating Committee of NHRIs with the exceptions of Honduras ('B status'). A status indicates that the NHRI is in full compliance with the Paris Principles. See http://nhri.ohchr.org/EN/Pages/default.aspx

${ }^{5}$ Interview with Verónica Gómez, co-director of the International Centre for Political Studies (CIEP), formerly advisor to the Argentina's Ministry of Foreign Affairs and IACHR specialist. Interview with Nataly Herrera, Buenos Aires, 15 August 2014.

${ }^{6}$ Remarks by Commissioner Felipe González Morales of the Inter-American Commission on Human Rights during the launch of the 2011 Annual Report on Human Rights of Chile's National Institute of Human Rights. ${ }^{7}$ A notable exception is the Colombian NHRI head who is appointed by the legislature from a short list provided by the President.

${ }^{8}$ See Pegram 2012 for a detailed breakdown of institutional features among Latin American NHRIs.

${ }^{9}$ A number of Latin American NHRIs are formally restricted to those rights enshrined in the national constitution or other restrictions. These include Argentina, Colombia, Costa Rica, Nicaragua and Paraguay. Although in practice, such formal restrictions have rarely constrained NHRIs.
} 
with the local context in which they operate. However, other NHRIs have notably imposed a narrow reading on their legal mandate. For example, Article 102, Section B of the Mexican Constitution states that the National Human Rights Commission is the body responsible for the 'protection of human rights established under Mexican law' and is empowered to hear 'complaints regarding acts or omissions of an administrative nature by any authority or public servant - with the exception of the federal judiciary - which violate these rights'. The Mexican Commission has interpreted this to mean that the entity is not empowered to petition the IACHR on behalf of claimants. Similarly, the Colombian office has not been involved in international litigation, with national law interpreted by the NHRI itself as precluding such activity. ${ }^{10}$ However, as explored below, its fact-finding role in providing information to both the IACHR and IACtHR has been important.

Evidently, not all NHRIs have the same jurisdictional remit with regards to international human rights law: much depends upon the domestic regulations in each country. Another key consideration is agency choice on the part of officials holding senior positions with the body as this will affect both the level of support the institution enjoys, as well as the way it decides to realise its institutional mandate in practice. ${ }^{11}$ Related to this, the relationship between the NHRI and organised civil society groups is both consequential and indicative. At its best, coordination can serve to mutually support joint action on human rights concerns, with civil society and NHRIs often collaborating in direct or indirect engagement with the IAHRS. However, it is also important to be attentive to less desirable outcomes, including competitive dynamics between these two sets of actors, and even conflict in situations where the independence of the NHRI or civil society organisations is in doubt.

\section{National human rights institutions and the Inter-American Human Rights System}

The rapid ascent of NHRIs as the normative 'vehicle of choice' is evident in the growth of dedicated infrastructure within the UN system (Pegram 2015). In contrast to the UN, the IAHRS has not formalised arrangements with regional NHRIs. However, Latin American scholars have addressed the potential role that NHRIs can play in 'the creation of a culture of

\footnotetext{
${ }^{10}$ Often, as in Colombia, national laws do not allow these institutions to take action against the state itself (of which they themselves are part) before an international court. The separation of powers doctrine is limited in cases where one part of the state seeks to file a legal complaint against another.

11 Verónica Gómez, 15 August 2014.
} 
respect for human rights which values the Inter-American Commission, the Court and its resolutions', while also cautioning against an uncritical assessment of what remain formally independent, but government-funded, agencies (Mendez and Aguilar 1997: 268). Drawing on their Iberian lineage, observers have derived inspiration from the Portuguese and Spanish NHRI's relationship to the European Convention on Human Rights, asserting that their Latin American peers are obliged to 'promote the diffusion and implementation' of the American Declaration of Human Rights and the Inter-American Convention on Human Rights (Santistevan 2004: 53).

Despite a lack of dedicated official infrastructure, the OAS has shown growing interest in NHRIs, signalled in 1997 by a declaration calling for their establishment in all member states. ${ }^{12}$ Similarly, a 2003 OAS General Assembly Resolution called for the strengthening of national systems for the promotion and protection of human rights in member states and the development of cooperative relations between the OAS and the Network of National Institutions for the Promotion and Protection of Human Rights in the Americas. ${ }^{13}$ The OAS has continued to promote the role of NHRIs in human rights protection and promotion, with a declaration in July 2008 that indicated an interest in facilitating interaction between national institutions and 'the organs, agencies and entities of the Organization'. ${ }^{14}$

A first-order question arises as to what may be the role of NHRIs according to the American Convention and IACtHR jurisprudence. As noted above, NHRIs in Latin America generally enjoy the investigative faculties required to perform a protective function. ${ }^{15}$ As such, they form part of a horizontal network of accountability agencies alongside the courts, public prosecutors and defenders, as well as actors at the sub-national level. Article 25(1) of the American Convention provides a right to judicial protection at the domestic level and the IACtHR has recognised that certain legal prerogatives of NHRIs, such as amparo and habeas corpus court actions fall within the meaning of Article 25(1). However, in the Bámaca Velasquez decision, the IACtHR noted that habeas corpus petitions and a special pre-trial

\footnotetext{
${ }^{12}$ OAS General Assembly: Support for International Exchanges Among Defensorías, OAS AG/RES 1505, XXVII-0/97 (June 5, 1997)

${ }^{13}$ OAS GA, Strengthening of Human Rights Systems Pursuant to the Plan of Action of the Third Summit of the Americas, OAS AG/RES 1925, XXXIII-O/03 (June 2003).

${ }^{14}$ Strengthening the role of NHRIs for the Promotion and Protection of Human Rights in the Organization of American States, AG/RES. 2421 (XXXVIII-O/08), adopted on June 3, 2008)

${ }^{15}$ The Chilean National Institute of Human Rights notably lacks the ability to receive complaints and many of the investigative faculties common in the region.
} 
investigation conducted by the Guatemalan NHRI proved ineffectual and the state was found to have violated Article 25(1). ${ }^{16}$ Similarly, in the more recent Contreras et al. decision, the IACtHR draws a clear distinction between the NHRI, on the one hand, and control agencies with binding authority, on the other, suggesting that an NHRI alone does not constitute effective judicial remedy:

...although a complaint before the Ombudsman's Office can result in effective and useful actions in cases of alleged human rights violations, it is clear that the facts denounced were also brought to the attention of the Office of the Prosecutor General whose responsibility it was to initiate the corresponding criminal proceedings. ${ }^{17}$

Beyond judicial remedy, members of the IACHR have acknowledged that the existence of such bodies contributes to a range of valuable compliance functions, including continual feedback on human rights issues of concern, disseminating information, monitoring and tracking of cases under review, as well as the implementation of international standards (both international instruments to which a state is party and the resolutions of international bodies responsible for their interpretation) in domestic law and practice. ${ }^{18}$ Such duties complement the Commission's own work and monitoring initiatives. More recently, NHRIs have been invited to participate in the ongoing IAHRS reform process and have featured in a number of civil society submissions to the IACHR. ${ }^{19}$

\section{Mapping Connections: National Institutions and the Inter-American Human Rights System}

In contrast to the UN system, the IAHRS is yet to develop a formal framework to govern NHRI participation. Nevertheless, NHRI engagement with the IAHRS, including the OAS General Assembly, the IACHR and the IACtHR, has been a feature of transgovernmental activity in Latin America since the early 1990s. Across countries, NHRIs have looked to the IAHRS for support in bolstering their domestic credibility, influence and guidance in

\footnotetext{
${ }^{16}$ Bámaca Velásquez Case, Judgement 25 November 2000.

${ }^{17}$ Contreras et al. vs. El Salvador case, Judgement 2011

${ }^{18}$ Remarks by Commissioner Felipe González Morales of the Inter-American Commission on Human Rights during the launch of the 2011 Annual Report on Human Rights of Chile's National Institute of Human Rights.

${ }^{19}$ See submission by Santa Clara University's International Human Rights Clinic, 4 October 2012. The Uruguayan NHRI submission can be viewed here: http://scm.oas.org/IDMS/Redirectpage.aspx?class=CP/INF.\&classNum=6542\&lang=S
} 
elaborating a human rights mandate. ${ }^{20}$ In turn, the IAHRS has engaged, albeit on an ad hoc basis, with those NHRIs viewed as credible and effective interlocutors at the local level. This reflects a wider agenda to enhance coordination with human rights stakeholders and the potential for NHRIs to assist resource-strapped Inter-American agencies to better understand local contexts, facilitate access to the IAHRS for victims, and monitor compliance with InterAmerican recommendations and decisions.

\subsection{NHRI Implementation Activities at the Domestic Level}

NHRIs have strengthened the impact of the IAHRS through their activities at the national level. NHRIs are well placed to mobilise in support of treaty ratification; monitor resolutions and judgments issued by the Court and Commission; test the limits of domestic remedies; publicly exhort the state to fulfil its human rights commitments in public statements; and, establish new precedents by drawing on IAHRS jurisprudence in national reports. NHRIs have made particular use of three principal tools to advance their international law mandates at the local level:

- Lobbying states to ratify international human rights treaties through public policy engagement

- Making legislative proposals to government and legislatures, as well as advising on draft legislation to ensure conformity with international obligations

- Presenting constitutional actions against laws which they regard as contravening rights enshrined in domestic law and/or ratified treaties

One of the most important roles Ombudsmen may play at the domestic level is to provide a focal point for mobilisation in support of implementation of international human rights standards. Many Latin American NHRIs can seek to strike down existing laws by submitting an action of unconstitutionality before their Constitutional Tribunal. NHRIs have drawn on IAHRS standards and jurisprudence in unconstitutionality petitions aimed at defending the

\footnotetext{
${ }^{20}$ For example, shortly after assuming office, the first Colombian Ombudsman, Jaime Cordoba Triviño, travelled to Washington in 1994 to address the IACHR on the domestic human rights situation. See Boletin de Prensa, 'El Defensor del Pueblo habla mañana ante Comisión de Derechos Humanos de la OEA', 19 September 1994.
} 
right to information, ${ }^{21}$ privacy, ${ }^{22}$ prior consultation for indigenous communities, ${ }^{23}$ and participation, ${ }^{24}$ among others.

NHRIs have also actively pursued compliance with decisions of the IAHRS. In the case of José Carlos Trujillo Oroza vs. Bolivia, the Bolivian Ombudsman sought to monitor and facilitate implementation of the ruling. ${ }^{25}$ This included a successful campaign of lobbying and legislative submissions to insert the crime of forced disappearances into the Bolivian penal code, as laid down by the IACtHR as one component of the reparation order. The Guatemalan NHRI has also engaged as an interlocutor between the IAHRS and domestic human rights organisations, supporting applications for provisional measures to be issued to ensure the physical protection of human rights defenders. ${ }^{26}$ More generally, Latin American NHRIs have used IACtHR rulings as a means to bolster their activities at the domestic level through the issuing of regular compliance reports. ${ }^{27}$

Education and public awareness activities conducted by NHRIs in domestic jurisdictions have often served to inform IAHRS proceedings. For example, the Chilean Human Rights Institute, in partnership with the UN Office of the High Commissioner for Human Rights, conducted a seminar in 2011 with international and national experts, civil society and state officials on terrorism and international human rights standards. The outcome document of the meeting was subsequently relied upon by the IACtHR in its ruling in the case of Norin Catriman y otros vs. Chile. Other NHRIs have pursued compliance with IACtHR rulings as a means to both mobilise domestic constituencies in support of restitution and to put pressure on public authorities to undertake preventative structural reform. For example, in following up on the ruling in Artavia Murillo y otros (en vitro fertilization) vs. Costa Rica, the Ombudsman forcibly criticised the inaction of the Costa Rican Social Security Authority and exhorted Congress to act, receiving considerable media coverage in the process. ${ }^{28}$

\footnotetext{
${ }^{21}$ See Acuerdo y Sentencia No. 1.306. Available at: http://www.pj.gov.py/contenido/945-informacionpublica/947

${ }_{22}$ PRADPI, 'La Sala IV admite la Acción de Inconstitucionalidad presentada por la Defensoría del Pueblo', 28 November 2012.

${ }^{23}$ Erbol, 'Defensor del Pueblo presenta recurso contra DS 2298', 31 August 2015.

${ }^{24}$ Servindi, 'Defensoría del Pueblo presenta demanda de inconstitucionalidad contra DL 1015', 1 June 2008.

${ }^{25}$ José Carlos Trujillo Oroza vs. Bolivia 2000

${ }^{26}$ See Masacre Plan de Sánchez vs. Guatemala, 29 April 2004.

${ }^{27} \mathrm{See}$, for example, multiple compliance reports produced by the El Salvadorian NHRI into the case of Hermanas Ernestina y Erlinda Serrano Cruz.

${ }^{28}$ See La Nación, Defensoría pide llamar a cuentas al Estado por incumplir fecundación in vitro’, 2 March 2015.
} 
However, it is important to note that while some NHRIs have actively worked to advance compliance with IAHRS rulings in domestic jurisdictions, this is not always straightforward. Notably, the Colombian NHRI states that 'within the Colombian state, the Ministry of Foreign Affairs is responsible for liaising with the IAHRS. In consequence, the Ombudsman plays a subsidiary role in the implementation of regional judicial norms and facilitating access to the system for victims'. ${ }^{29}$ The Colombian office has emphasised resolution of human rights violations at the domestic level, for example, submitting legislative projects to strengthen extraordinary protection mechanisms (acción de tutela) for victims of human rights violations. ${ }^{30}$ The case of Venezuela poses a particular challenge, with the Ombudsman conspicuously silent in pronouncing on the 2013 decision by the government to withdraw from the jurisdiction of the Court. ${ }^{31}$ The Ombudsman has since publicly questioned the independence of the IACHR. ${ }^{32}$

\subsection{NHRI Compliance Activities at the International Level}

NHRIs in Latin America, often in coordination with human rights organisations and individual litigants, may perform an important function in acting as a gateway to international tribunals for victims of human rights violations once domestic remedy has been exhausted. This section presents a mapping exercise of the interactive linkages between NHRIs, the Commission and the Court. We then turn to exploring in more depth this relationship in light of current developments and possibilities for further deepening interactive linkages.

\section{A. The Commission and National Human Rights Institutions}

The IACHR performs a quasi-judicial role as a first-stage complaint mechanism within the IAHRS. Conceptually, NHRI practitioners have described the IACHR as acting akin to 'a collegiate Ombudsman for human rights', noting the affinity in a modus operandi informed by a lack of legally binding authority and the potential for court referral (Santistevan 2004:

\footnotetext{
${ }^{29}$ Letter to Dr Tom Pegram from Javier Orlando Tamayo Perdomo, Director of National Attention and Complaints, Colombian Defensoría del Pueblo, 4 February 2014.

${ }^{30}$ See Noticias RCN, 'Defensoría del Pueblo presenta proyecto que busca reformar la acción de tutela', 29 July 2015.

${ }^{31}$ See El Universal, 'ONU le da un año al Defensor para probar que es independiente del Gobierno', 29 May 2015.

32 'Defensor del Pueblo plantea creación de organismo similar a la CIDH', 2 June 2015. Available at: http://www.2001.com.ve/en-la-agenda/99278/defensor-del-pueblo-plantea-creacion-de-organismo-similar-a-lacidh.html
} 
54). Importantly, NHRIs have standing to petition the IACHR on behalf of individuals or groups of individuals alleged to have had their rights violated. For the purposes of the Convention, in a series of decisions, the Commission has recognised NHRIs as 'persons' and therefore legitimate petitioners (Reif 2004). The Commission has entered into institutional agreements with individual NHRIs in Latin America, with the objective of 'establishing institutional links of collaboration with a view to...the mutual strengthening of both institutions. ${ }^{33}$

In 1996, the Argentinean NHRI lodged an appeal with the IACHR, alleging a violation of the rights of more than 65,000 pensioners. In parallel, the NHRI opened a domestic investigation highlighting the failure of the State and court system to rule on the matter. The IACHR opened a file on the NHRI's complaint in order to determine admissibility. However, before the Commission could formally rule on its admissibility the NHRI withdrew the petition following resolution by the Argentinean Supreme Court. As Mendez and Aguilar (1997: 273) note, this was a pioneering example of an NHRI successfully dovetailing a domestic and international compliance strategy. Confirmation of the NHRI's formal standing as a petitioner came in 2002 when the Peruvian NHRI submitted a petition in the Janet Espinoza case. The IACHR did not question the ability of the NHRI to lodge the petition. ${ }^{34}$

In reviewing the admissibility of petitions, the IACHR has engaged with NHRIs at each stage of the process. More broadly, as detailed below, a survey of NHRI activities reveals that they have submitted petitions, or been named as co-petitioners, have sought precautionary measures on behalf of claimants, and have participated in and requested public hearings. In terms of fact-finding, NHRIs have been afforded special audiences with the IACHR to advise on the facts of active cases. ${ }^{35}$ The role of the Colombian NHRI, for example, in providing information to both the Commission and Court has been very important, although the NHRI has not engaged in international litigation. ${ }^{36}$ Reports by NHRIs have been presented to the Commission directly as well as used in loco visits and special rapporteur investigations. NHRIs have also served as 'friends of the Commission' though amicus curiae briefs. In other instances, the IACHR has designated NHRI personnel as legal experts to advise on

\footnotetext{
${ }^{33}$ See 'Acuerdo de Cooperación General entre La Secretaria General de La Organización de los Estados Americanos y La Comisión de Derechos Humanos del Distrito Federal de los Estados Unidos Mexicanos', 18 October 2012.

${ }^{34}$ Janet Espinoza Feria Case, Admissibility, Case No. 12,404 (10 October 2002)

${ }^{35}$ Siglo 21, 'Pide a CIDH mediar para evitar contaminación minera de Guatemala', 10 January 2013

36 Verónica Gómez, 15 August 2014.
} 
domestic law concerning issues such as military versus civilian jurisdiction, public administration law and electoral legislation pertaining to gender quotas (Santistevan 2004: 55-6). The most active NHRIs within the IAHRS have dedicated legal personnel experts in accessing domestic and international tribunals (Chipoco 2001). Indeed, one submission to the review process of the IAHRS advocated greater engagement with NHRIs to improve the current admissibility rate of 10 percent. $^{37}$

In terms of outcome, a number of petitions to the IACHR by the Bolivian NHRI for redress, for example, have resulted in friendly settlements, following a finding against the State by the Commission. Notably, the Bolivian NHRI has monitored follow-up and compliance with the terms of the friendly settlement agreements. In a series of final decisions, the IACHR deferred to the Bolivian NHRI in declaring the terms of the friendly settlement to be complied with and recommending the case to be closed. ${ }^{38}$ Where an amicable settlement has not been achieved, NHRI petitions have proceeded to the IACtHR. ${ }^{39}$

\section{B. The Court and National Human Rights Institutions}

Observers have noted an absence of rules for formal participation of NHRIs in compliance proceedings before the Court (Open Justice 2013: 98). According to Article 63 of the Court's rules of procedure, the submission of compliance monitoring reports is restricted to states and to victims or their legal representatives. NHRIs may submit information but only at the Court's discretion. Nevertheless, in recent years, the IACtHR has signed Inter-Institutional Agreements of Cooperation with NHRIs in Ecuador and Peru (IACtHR 2010: 21). Most recently, the Court entered into a cooperation agreement with the Colombian Ombudsman, with the President of the Court emphasising the importance of Human Rights Ombudsmen in the Americas as responsible for the promotion, protection and defence of human rights. ${ }^{40}$ NHRIs may be particularly well-placed to undertake monitoring and compliance activities.

\footnotetext{
${ }^{37}$ Submission to Executive Secretary of the IACHR by the International Human Rights Clinic, Santa Clara University School of Law, 4 October 2012.

${ }^{38}$ See Alfredo Díaz Bustos vs. Bolivia 2005; Víctor Hugo Arce Chavez vs. Bolivia 2007; Miguel Ángel Moncado Osorio and James David Rocha Terraza vs. Bolivia 2007.

${ }^{39}$ For example, Ticona Estrada y Otros vs. Bolivia, 2008.

${ }^{40}$ See Comunicado de Prensa, 'Defensoría del Pueblo de Colombia firma convenio con Corte Interamericana de Derechos Humanos', 2 February 2015.
} 
Legal scholars have advanced a number of proposals regarding the appropriate role of NHRIs before the IACtHRs. Mendez and Aguilar (1997: 273-4) suggest that NHRI petitions should be limited to class actions. They also warn against using NHRIs as a means to rationalise the number of petitions from individuals. However, Reif (2004: 179) counters that NHRIs should not be barred from submitting individual protection submissions. In light of the New Rules of Procedure published by the IACHR in 2009 and the creation of the innovative InterAmerican Public Defender to assist victims who lack legal representation to appear before the court, Dulitzky (2011: 154) proposes to include NHRIs among those agencies which could perform this function within the IAHRS. The remainder of this section draws on IACtHR proceedings to map out the various roles which NHRIs have performed in Court proceedings:

Amicus curiae briefs: NHRIs have increasingly submitted amicus curiae briefs, with the leave of the court. This is the most common form of engagement. The Peruvian NHRI has been particularly active in this regard, submitting the first amicus brief in $1997 .{ }^{41}$ NHRIs in Ecuador, El Salvador and Panama have also participated in proceedings as 'friends of the court'. ${ }^{42}$ In Gonzales Lluy y otros vs. Ecuador, the Ombudsman presented an amicus curiae brief on behalf of the complainant with a detailed analysis of rights intended to serve as:

[A] basis to orientate the decision of the Interamerican Court of Human Rights to strengthen an evolutionary interpretation that guarantees the enforceability of the right to health and education in those cases related to children and adolescents with HIV/AIDS... ${ }^{43}$

Expert witness: The IACtHR has on various occasions designated personnel or former functionaries of NHRIs as expert witnesses during proceedings. ${ }^{44}$ Again, members of the Peruvian NHRI have led the way in offering their expertise to the Court on interpretation of

\footnotetext{
${ }^{41}$ See Also case of Barrios Altos et al. v. Peru 2001; Case of the "Five Pensioners" vs. Peru 2003; Case of Acevedo-Jaramillo et al. vs. Peru 2006

${ }^{42}$ See Gonzales Lluy y otros vs. Ecuador 2015; Case of Baena-Ricardo et al. vs. Panama 2001; Case of Masacres del Mozote vs. El Salvador 2012

${ }^{43}$ Gonzales Lluy y otros vs. Ecuador 2015, presented by the Defensoría del Pueblo, Ecuador, May 2015, para. 45.

${ }^{44}$ See case of García Prieto et al. vs. El Salvador 2007; Masacres del Mozote y lugares aledaños vs. El Salvador 2012; Case of Juan Humberto Sánchez vs. Honduras 2003; also Ibsen Cárdenas and Ibsen Peña vs. Bolivia.
} 
the Constitution and laws. ${ }^{45}$ The Commission has proposed NHRI personnel as expert witnesses, as well as drawn on special reports issued by NHRIs in support of its interpretation of the law before the IACtHR ${ }^{46}$ NHRI personnel have also served as the "common intervener' at the invitation of the Commission. ${ }^{47}$ The El Salvadorian NHRI has played a particularly active role before the IACtHR. In the 2014 case of Hermanas Serrano Cruz, the testimony of the NHRI head, David Morales Cruz, served to establish the existence of a responsible party in the forced disappearance of children during the country's internal conflict. ${ }^{48}$ Notably, the court ruling in this case cited the NHRI's testimony.

Fact-finding: The IACtHR has made extensive use of NHRI special reports to highlight a lack of compliance at the local level, ${ }^{49}$ to ascertain the nature of the violation as well as its scope ${ }^{50}$ to prove the alleged context within which the violations occurred, ${ }^{51}$ and to ascertain responsibility. ${ }^{52}$ In Juan Humberto Sánchez vs. Honduras, the Court included a report by the NHRI as documentary evidence, noting that its findings were not challenged by the State. ${ }^{53}$ Similarly, in Bulacio vs. Argentina, the Court used a report by the Defensoría del Pueblo of Buenos Aires to determine the illegality of the widespread practice of "razzia" (massive detention). ${ }^{54}$ There are multiple examples of NHRI documentation and reports being relied upon by the IACtHR in its judgements. ${ }^{55}$ Notably, the Court requested information directly from the Ombudsman in Marino López y otros (Operación Génesis) vs. Colombia [2013].

Provisional measures: NHRIs have been active in providing recourse to individuals under threat in the course of human rights investigations. The Guatemalan NHRI has evacuated victims and human rights activists faced with death threats (Inter-American Yearbook on

\footnotetext{
${ }^{45}$ See Case of Ivcher-Bronstein vs. Peru 2001; Case of Lori Berenson-Mejía vs. Peru 2004; Case of AcevedoJaramillo et al. v. Peru 2006;

${ }^{46}$ See Case of Barrios Altos vs. Peru 2001; Case of Gómez-Palomino v. Peru 2005.

${ }^{47}$ Where there is more than one victim, a 'common intervener' must be designated. See case of García Prieto et al. vs. El Salvador 2007

${ }^{48}$ See Hermanas Serrano Cruz vs. El Salvador 2014

${ }^{49}$ Case of Acevedo-Jaramillo et al. vs. Peru 2006

${ }^{50}$ See case of García Prieto et al. vs. El Salvador 2007. In Manuel Cepeda Vargas vs. Colombia 2010, the Court makes extensive use of an NHRI report into the murder of members of the Patriotic Union party, referring to the NHRI's verdict that the scale of the violence amounted to 'systematized extermination'. See also case of García Prieto et al. vs. El Salvador 2007

${ }^{51}$ See Case of Barrios Altos vs. Peru 2001

52 In Masacres del Mozote vs. El Salvador 2012, the IACtHR notes that the El Salvadorian NHRI established that the 'massacres occurred within the framework of military operations, one of the objectives of which was the mass extermination of civilians...'

53 Juan Humberto Sánchez vs. Honduras 2003

${ }^{54}$ See Bulacio vs. Argentina, 2003.

${ }^{55}$ See also Masacres del Mozote y lugares aledaños vs. El Salvador 2012.
} 
Human Rights 1991: 1094). The Colombian office has been particularly active in monitoring provisional measures issued by the IACHR and IACtHR. ${ }^{56}$ Colombian NHRI personnel themselves have also been subject to threats and assassinations. ${ }^{57}$ The Court has directly requested information from NHRIs (as opposed to the state) when assessing the faithful execution of provisional measures. ${ }^{58}$

Reparations and compliance: on occasion, Ombudsmen have represented victims before the IACtHRs. For example, the Bolivian Ombudsman represented the victims in the case of Renato Ticona vs. Bolivia. Victims of human rights violations have requested that NHRIs perform symbolic acts of repentance on behalf of the state. ${ }^{59}$ NHRIs have presented compliance briefs to the IACtHR. ${ }^{60}$ Indeed, States have instructed NHRIs to prepare compliance reports as a means of preventing a case proceeding to the IACtHR. ${ }^{61}$ Méndez and Aguilar (1997: 260) highlight the role NHRIs can play in promotion of IAHRS decisions. NHRIs have been requested to engage in training of justice administrators. ${ }^{62}$ Dulitzky (2011: 163) calls for a concerted effort towards creating domestic compliance mechanisms which include NHRIs among a multi-member body comprising state and non-governmental actors.

In a novel recent development, the IACtHR has begun to accept requests from NHRIs to participate in formal public audiences on compliance actions taken by the state. The Costa Rica Human Rights Ombudsman's request to participate in a 2015 public hearing on steps taken by Costa Rica to comply with the ruling in Artavia Murillo y otros (en vitro fertilization) vs. Costa Rica was accepted by the Court. The request was accepted 'in conformity with Article 69.2 of the Court's Regulation, with the objective of receiving another source of information, distinct from the state in its capacity as party to the process, which permits the Court to evaluate compliance of guarantee of non-repetition in the present case'. ${ }^{63}$ In general terms, the IACtHR does not permit interventions by third parties. However, for Court observers, the intervention of the Costa Rican NHRI has been viewed

\footnotetext{
${ }^{56}$ See El Tiempo, 'El Defensor del Pueblo solicita protección especial para una Defensora Comunitaria víctima de atentado', 15 May 2013; FIO, 'Amenazas proferidas contra miembros de ONGs líderes sociales y una funcionaria de la Defensoría del Pueblo', 9 June 2011.

${ }^{57}$ El Tiempo, 'Asesinaron a defensor público en Cali', 7 October 2011.

${ }^{58}$ See IACtHR Resolution, Cuatro Comunidades Indigenas Ngöbe y sus Miembros, 28 May 2010.

${ }^{59}$ See case of La Cantuta vs. Peru 2006

${ }^{60}$ See case of Baena-Ricardo et al. vs. Panama 2003

${ }^{61}$ See case of the 19 Merchants vs. Colombia 2002

${ }^{62}$ See case of Anzualdo Castro vs. Peru 2009

${ }^{63}$ See Caso Artavia Murillo y otros (Fecundación In Vitro') vs. Costa Rica, 3 September 2015.
} 
positively. ${ }^{64}$ Among a number of emerging functions then, perhaps the most important role of NHRIs vis-à-vis the Court is to make visible the steps taken to comply with its rulings, as well as to reinforce to states the necessity of compliance.

\section{The Experience of the Peruvian Human Rights Ombudsman: From Exit to Internalisation}

This case study of the Peruvian NHRI exemplifies the actual and potential engagement between these institutions and the IAHRS. The Peruvian Human Rights Ombudsman is emblematic of the challenges many ombudsmen in the region confront. The office is distinctive among its peers for having managed to carve out a high degree of independence and effective action. Amid a sea of institutional disorder, one surprising constant has been the small island of functionality that is the Ombudsman. From its creation in 1996 to the fall of the Fujimori dictatorship in 2000, the Ombudsman operated, practically, as the sole democratic agent of accountability within the state (Pegram 2008). The institution has also proved capable of adapting to new political circumstances, consistently achieving public approval ratings of $50 \%$ and above. ${ }^{65}$ Engagement of the Peruvian Human Rights Ombudsman with the Commission and Court can be broadly separated into two periods: preand post transition to democracy in late 2000 .

As this case study highlights, a shifting political and institutional context has shaped the evolving relationship between the Peruvian NHRI and the IAHRS. The IAHRS served as a vital external resource for an embattled Ombudsman and civil society during the autocratic regime of Fujimori, evidenced in multiple petitions and interventions. Post-transition to democracy, the relationship has become less overt but no less important. An initial democratic spring under the interim government of Valentin Paniagua (2000-2001) served to mutually reinforce the bonds between NHRI and IAHRS. But in recent years this initial optimism has given way to a troubled process of faltering democratic re-institutionalisation in Peru. In this setting, the Ombudsman has sought to advance human rights reform through internal channels and frequently invokes the IAHRS in this endeavour. Observers highlight the continuing significance of the IAHRS in the activities of the NHRI and vice versa, but

\footnotetext{
${ }^{64}$ Oscar Parra Vera, Senior Legal Advisor, Interamerican Court of Human Rights, by email with Tom Pegram, 10 October 2015.

${ }^{65}$ See GfK Perú - Encuesta de opinión pública - July 2014. Available at: www.gfk.pe
} 
also the challenges posed by the system's perceived distance from the realities of human rights politics on the ground. The Peruvian experience suggests that the Commission and Court have been slow to respond to opportunities for deepening engagement with national institutions. For its part, the Ombudsman indicates a continued willingness to engage with the IAHRS where possible.

\subsection{Setting the scene}

The Peruvian Human Rights Ombudsman - or Defensoria del Pueblo - was created under the 1993 Constitution. ${ }^{66}$ It has a constitutional mandate to protect and promote the fundamental rights of individuals and the community and displays a wide range of investigative and promotional tools, including complaint-handling powers, court referral authority, ex officio investigative prerogatives and the ability to engage with international organisations and promote harmonisation of domestic legislation with international human rights instruments and standards. Throughout the 1990s, the IAHRS supported the work of the Peruvian NHRI. Prior to the creation of the Ombudsman office, the Inter-American Commission had strongly recommended the establishment of such an agency. ${ }^{67}$ In its 2000 country report on Peru it delivered a positive report on the impact of the Ombudsman. ${ }^{68}$ In a context defined by two decades of widespread, systematic and egregious violations, there was no shortage of serious human rights concerns. This explains, in large part, why Peru remains the country with the most petitions pending before the IACHR in the region.

In 1998, the Commission conducted a visit to Peru to observe the general human rights situation in the country. As part of the in loco visit, representatives from the Commission met with a number of senior government officials, including the Ombudsman, Jorge Santistevan, and senior staff. The Ombudsman's Office used the opportunity provided by the visit to report to the Commission on its investigation into a highly controversial government

\footnotetext{
66 Article 161: The Ombudsman's Office is autonomous. State agencies are obliged to cooperate with the Ombudsman's Office when so required. Its structure at the national level is set out by law. The Ombudsman may be elected or dismissed by a congressional vote with a two-thirds majority. The institution enjoys the same immunity and prerogatives as Congress. In order to be elected as Ombudsman, an individual must be over the age of 35 and be a qualified lawyer. The term of the Ombudsman is five years and is not subject to mandatory instructions.

67 http://www.cidh.org/countryrep/Peru93sp/anexo.3.htm

68 IACHR. Second Country Report. Peru 2000. http://www.cidh.org/countryrep/Peru2000sp/introduccion.htm
} 
programme of forced sterilisations in the country. ${ }^{69}$ In turn, the Peruvian Ombudsman strongly defended the role of the IAHRS in the face of opposition from the Fujimori government. In 1999, President Fujimori launched a campaign to withdraw Peru with immediate effect from the Court's jurisdiction. ${ }^{70}$ At considerable risk, the Ombudsman, Jorge Santistevan, exhorted Congress to reject this decision. ${ }^{71}$ Despite a growing chorus of objections by international and domestic observers, Congress approved the withdrawal. ${ }^{72}$ For his part, Santistevan became the focus of a proposed congressional investigation for misconduct shortly afterwards (Pegram 2008: 77).

However, the Ombudsman's actions were vindicated in 2001 following Fujimori's downfall. President Paniagua's assumed office in November 2000 and immediately set to work stewarding a transition to democracy and re-institutionalising the rule of law in Peru. It was in this context that Peru returned to the jurisdiction of the Court in January 2001. In a short lived democratic spring, human rights activists and allies formed part of Paniagua's transitional government with the Ombudsman assuming a principal advisory function to the President (Pegram 2011: 236). In hindsight, this was the high watermark for relations with the IAHRS and set in motion important processes, including the Truth and Reconciliation Commission (TRC). However, while President Alejandro Toledo (2001-2006) did not actively seek to undermine the IAHRS, conditions quickly deteriorated under his successors' administrations. Both Presidents Alan Garcia (2006-2011) and Ollanta Humala (2011-) stand accused of human rights violations during the 1980s. Under both administrations, human rights protections have been actively eroded (APRODEH 2008). The Ombudsman has continued to support the IAHRS at the domestic level. However, the task has become more difficult, confronting a concerted effort by powerful political factions to paint the IAHRS as biased, partisan and - particularly inflammatory in the Peruvian context - a supporter of terrorism. $^{73}$

\subsection{The Peruvian Ombudsman and the IAHRS}

69 During the in loco visit to Peru, for example, the Ombudsman's Office informed the IACHR that it had received 168 petitions regarding forced sterilisations. IACHR. Second Country Report. Peru 2000. Chapter IV, item 23 and throughout http://www.cidh.org/countryrep/Peru2000sp/capitulo7.htm

${ }^{70}$ Memorandum No. 328-99-JUS / DM, 2 July 1999.

${ }^{71}$ Document No DP-99-462, 6 June 1999.

${ }^{72}$ Ombudsman's Report: In Defence of the Inter-American System

${ }^{73}$ La Razón, 'Al apoyar terroristas, CIDH comete errores contra Perú', 24 May 2015. The ruling of the IACtHR in Eduardo Nicolás Cruz Sánchez (Chavín de Huántar) vs. Peru [2015] has provoked particular backlash among powerful factions in Peru. 
The Peruvian Ombudsman enjoys a range of powers which make it an attractive interlocutor for the IAHRS at the domestic level. Formally, the office has a broad and unrestrictive rights mandate and is instructed to 'promote the signature, ratification, implementation and effective diffusion of international human rights treaties'. ${ }^{74}$ The office's standing as a constitutional body, with the Ombudsman enjoying status equivalent to that of a high court judge, combined with high public approval, combine to give the office an unusual degree of prestige. This has served to bolster the Ombudsman's role in the education and promotion of human rights at the domestic level. The office is tasked with a mandate to facilitate greater public awareness of human rights through information campaigns, education programmes, and training of public officials. Importantly, the institution can also intervene in the political policy process, with the ability to submit legislative projects as well as initiate constitutional review actions against legislation which falls foul of human rights guarantees.

The office may lack binding enforcement authority. However, its status as a 'magistrate of persuasion' is buttressed by a series of quasi-judicial functions, including the ability to bring legal actions before the Peruvian Constitutional Court (Santistevan 2000). The office is empowered to investigate, either on receipt of an individual complaint or at its own initiative, any issue which it deems to fall within a broad and unrestrictive human rights mandate. The Peruvian office has also pursued legal redress, including habeas corpus, habeas data, amparo and amicus curiae briefs action, ${ }^{75}$ both on behalf of individuals and as a means to challenge systemic human rights violations. ${ }^{76}$ It is the amicus curiae (friend of the court) role of the office which has perhaps gained the most widespread acceptance and recognition within the IAHRS. As noted above, it was the Peruvian office which secured official sanction from the IACHR to intervene as amicus at the international level, with a series of rulings drawing on information submitted by the NHRI, along with opinio juris derived from its experience. ${ }^{77}$

\subsection{The Peruvian Ombudsman and the IAHRS: From Exit to Internalisation}

\footnotetext{
${ }^{74}$ Organic Law No. 26520, 8 August 1995, Article 9(5)

${ }^{75}$ Amparos (emergency writs for the protection of constitutional rights) and habeas corpus (protection from unlawful detention) reflect regional legal traditions for the protection of individual rights. Habeas data refers to freedom of information petitions.

${ }^{76}$ Ombudsman's Office. "El amicus curiae: ¿qué es y para qué sirve? Jurisprudencia y labor de la Defensoría del Pueblo". Ombudsman Document Series - Document No. 8. 2nd edition. Lima, March 2010.

${ }^{77}$ Méndez, Juan and Irene Aguilar. La relación entre el Ombudsman y el Derecho Internacional de los Derechos Humanos: II Congreso Anual de la Federación Iberoamericana de Defensores del Pueblo. Toledo, April 1997.
} 
Employing an expansive interpretation of its mandate, the Peruvian NHRI has pioneered a raft of engagement strategies with the IAHRS. It has played a significant role in advancing the rights of Peruvians before both the Inter-American Commission and Court of Human Rights, particularly during the Fujimori dictatorship. ${ }^{78}$ This has been guided, in large part, by the objectives of senior personnel within the Ombudsman institution, and, above all, the head of the office (the Defensor). As one senior official puts it, "the Ombudsman is marked by the leadership of individual Defensors. In the end, it is the Defensor who decides. The first two Defensors, Santistevan and [Walter] Alban were both litigators, I think this is important to take into account". ${ }^{79}$ It is notable that during the tenure of Jorge Santistevan (1996-2000) and Walter Alban (2000-2005), direct engagement with IAHRS legal procedures was a regular occurrence. Under the leadership of their successors, Beatriz Merino (2005-2011) and Eduardo Vega (2011- ), emphasis has been placed on seeking redress at the domestic level with no litigation pursued at the IAHRS. The IAHRS has instead been employed indirectly, to buttress Ombudsman mobilisation efforts. The following discussion demarcates this strategic evolution broadly across these two time periods.

\section{6-2001: Exhausting Domestic Remedy and Exit}

If its first five years was marked by the Ombudsman regularly accessing the IAHRS, the strategy has notably shifted since 2001. Beyond leadership, this move from exit (the ombudsman seeking remedy internationally) to internalisation (the ombudsman incorporating IAHRS standards in pursuit of domestic remedy) must also be placed in the context of newly democratic state structures and multiplying rights issues at the domestic level. Under Fujimori, the priority was massive violations of civil and political rights, which meant a focus on issues ranging from torture, to extra-judicial execution, the military judicial system and freedom of the press, among others (Pegram 2008). These rights issues confronted an increasingly autocratic executive, willing and able to exercise de facto veto power over domestic remedy. The escalating assault by Fujimori on rule of law institutions in Peru is well-documented, with the effective dismantling of the Constitutional Tribunal, the use of "faceless judges" and impunity laws, among the most egregious examples (Youngers 2000).

78 IACHR. Second Country Report. Peru 2000. Chapter I, item 46. http://www.cidh.org/countryrep/Peru2000sp/capitulo1.htm

${ }^{79}$ Fernando Castaneda, interview 11 September 2015. 
Given the limited potential for domestic remedy, Santistevan, supported by the legal expertise of both Alban (serving as Deputy Ombudsman) and Samuel Abad, proved ready to defy the regime by seeking remedy at the IAHRS, garnering support from domestic and international human rights observers in the process.

Outlined below are those emblematic legal cases in which the Ombudsman has been directly involved. Notably, Abad highlights that their strategy during this era was to limit litigation actions to those cases deemed emblematic so as to avoid becoming a de facto public defenders' office. ${ }^{80}$

\section{A. Gender quotas: Janet Espinoza et al. vs. Peru [2002] (IACHR)}

In August 2001, representatives of the Ombudsman's Office and the Manuela Ramos Movement filed a petition before the IACHR regarding elections held on 8 April 2001. The petition alleged violation of a number of rights recognised in the American Convention on Human Rights, including the right to participate in government, equal protection, and freedom from discrimination. The petition was filed on behalf of female congressional candidates in the electoral districts of Callao, Ica and La Libertad, as well as female voters. The petition was admitted on 10 October 2001 and assigned the number 12,404.

In response, the Executive Secretary of the IACHR forwarded to the Ombudsman's Office the Peruvian state response in March 2002. The state argued that the petitioners could not yet defer to international mechanisms as domestic remedies had not been exhausted. It continued, the petitioners had failed to submit a 'special appeal for nullity' against resolution 295-2001JNE (which had rejected a domestic appeal filed by the Ombudsman against Resolution No. 029 -2001-JEEI). The response also stated that Article 116 of the Electoral Law, which establishes minimum quotas for men and women in parliamentary lists, forbade lists from being the exclusive domain of either sex, declaring that it would represent 'discrimination against the population in general if all candidates are women, and men are excluded'.

80 Interview with Samuel Abad, Constitutional lawyer and former commissioner at the Ombudsman's Office, Lima, 18 September 2014. 
Perhaps reflecting the sensitive nature of electoral politics, little progress has been made on the case. In 2008, the Manuela Ramos Movement, in its capacity as co-petitioner, submitted a proposal for a friendly settlement of the case. This called for the state to accept liability for violating women's right in the districts of Callao, Ica and La Libertad, in elections from 2001 onwards. ${ }^{81}$ It also required that the state pass a law modifying rules on electoral quotas for women and declaring an affirmative action policy. The Ombudsman's Office, in turn, submitted a proposal to the IACHR which sought to bring the parties together to reach a friendly settlement. ${ }^{82}$ The Ombudsman recommended that an official admission of liability be made in public in the presence of representatives from the National Jury of Elections (JNE) and that the apology be broadcast nationwide on the state television channel. The Ombudsman's Office further recommended a series of measures to ensure greater political participation by women. Resolution of this case is still pending, with the JNE continuing to evaluate the friendly settlement agreement.

\section{B. Cesti-Hurtado vs. Peru [1999] (IACtHR)}

This case concerned a retired member of the Peruvian Army who was unjustly detained, imprisoned and sentenced by the military justice system for fraud and dereliction of duty in 1996. The Ombudsman performed a number of actions before the IACtHR in pursuing international redress for Mr Cesti-Hurtado, as outlined below.

Expert witness: The Ombudsman intervened in the preliminary objections stage of the case before the IACtHR. Its intervention ensured compliance with a determinative ruling of habeas corpus which had earlier been granted to the petitioner, but which military courts had refused to accept. Interestingly, the IACHR appointed the Deputy Ombudsman for Constitutional Affairs, Samuel Abad, to act as expert witness before the IACtHR. During the hearing, Abad repeated the recommendation published by the Ombudsman that the Supreme Council of Military Justice was duty bound to comply with the habeas corpus order. ${ }^{83}$ The NHRI regarded the case as important not only for the individual complainant, but also for

\footnotetext{
81 Regional and municipal elections of 2002, as well as ballots for regional representatives and the Andean parliament in 2006 .

${ }^{82}$ Note No. 232-2008 / DP 5 September 2008

${ }^{83}$ See DP Resolution No. 012-97 / DP of 24 March 241997
} 
establishing limits on military jurisdiction. ${ }^{84}$ The office has continued to campaign for reform of the military justice system. ${ }^{85}$

Intervention as amicus curiae: In response to the Supreme Council of Military Justice's failure to comply with a habeas corpus order granted by a civilian court, the Peruvian High Court, in 1998, the Ombudsman was instructed by the complainant to participate as amicus curiae. ${ }^{86}$ The Ombudsman ultimately agreed, basing its decision on the protection of $\mathrm{Mr}$ Cesti Hurtado's right to freedom, as well as the important precedent which could be established for the applicability of habeas corpus orders. An amicus curiae brief was submitted to the IACtHR in March 1997. The document argued that a provisional measure should be issued immediately to compel the Peruvian authorities to comply with the habeas corpus judgment. The Ombudsman argued that this was required due to the extreme gravity of the threat, the urgency of the action required, and the need to avoid irreparable damage. ${ }^{87}$ In September 1999, the IACtHR ordered his immediate release. ${ }^{88}$ The Peruvian government complied on 10 November 1999.

\section{Barrios Altos vs. Peru [2001] (IACtHR)}

In this emblematic case of state sanctioned impunity, the Peruvian Ombudsman played an important role as amicus curiae in establishing the general applicability of the prohibition of amnesty laws in the case of gross human rights violations.

Law No. 26479 issued in June 1995 granted amnesty to military, police and civilian personnel who had committed crimes in the context of anti-terrorism operations. The measure was designed to grant retroactive immunity precisely at a time the Barrios Altos massacre of 1991 was under investigation by judicial authorities. Despite Law 26479, both the prosecutor and investigating judge continued to pursue their investigations, arguing that the new legislation was unconstitutional. In response, Congress passed Law No. 26492, forcing the investigation to be shut down.

\footnotetext{
${ }^{84}$ See DP report 'Lineamientos para la reforma de la justicia militar en el Perú', 1997.

${ }^{85}$ See DP report '¿Quién juzga qué? Justicia Militar Vs. Justicia Ordinaria.El delito de función en la jurisprudencia del Tribunal Constitucional y la Corte Interamericana de Derechos Humanos, 2002.

${ }^{86}$ File No 926-97/DP-OP.

87 Ombudsman's Office. Second Annual Report. Peru.

${ }^{88}$ Case of Cesti-Hurtado v. Peru, judgement of 29 September 1999.
} 
In response, the Peruvian NGO National Human Rights Coordinator, submitted a petition to the IACHR, requesting precautionary measures to prevent the application of Law No. 26479 and protect vulnerable individuals, which were duly granted. A range of NGOs then submitted claims for redress on behalf of the victims and relatives to the IACHR. Following a lack of progress in communications between the Commission and state, the case was forwarded to the IACtHR in June 2000. In March 2001, the IACtHR issued its ruling stating that the amnesty laws contravened the American Convention and the existence of amnesty legislation constituted a failure by the Peruvian state to harmonise domestic legislation with its international obligations. Accordingly, the amnesty laws 'lack[ed] legal effect'.

The role of the Ombudsman was decisive during the Court's interpretation of the judgment in March 2001. Intervening as amicus, the Ombudsman argued that the ruling should have general effect. The office contended that the striking down of Laws No. 26579 and 26492 established a general prohibition on amnesty legislation in cases of human rights violations. The legal argument had been carefully elaborated in an Ombudsman Report which was submitted to the court, recommending a number of measures required to ensure fulfilment of constitutional obligations to guarantee human rights. ${ }^{89}$ In August 2001, following a request for clarification from the Peruvian government, the Commission deferred to the Court on the general application of the ruling. On 3 September 2001, the Court ruled that the decision did indeed have general effect, referring explicitly to the Ombudsman report submitted as part of its amicus intervention.

\section{Other relevant actions}

The Peruvian Ombudsman was involved in a number of other cases before the Commission regarding violations linked to the Fujimori government's arbitrary exercise of power. For example, the office served as amicus in the defence of retired general Rodolfo Robles, who suffered violations of his rights after publicly releasing information about Peruvian military involvement in murders. ${ }^{90}$ Similarly, criticism of the government by journalists at Red Global and Radio 1160, owned by businessmen Baruch Ivcher and Genaro Delgado Parker, resulted in two judicial actions to remove their control of media channels, and an attempt to strip Ivcher of his Peruvian citizenship. Lawyers acting on behalf of Ivcher approached the

\footnotetext{
${ }^{89}$ DP Report, No. 57 of May 2001, Amnesty vs. Human rights: Seeking justice

${ }^{90}$ See Rodolfo Robles Espinoza v. Peru [1999]
} 
Ombudsman office to intervene on his behalf at the IACHR. In July 1997, the case was submitted to the IACtHR, with Samuel Abad serving as an expert witness, and ultimately leading to a ruling against the Peruvian government. ${ }^{91}$ In the judgement, the IACtHR again made mention of a detailed report on freedom of expression in Peru published by the Ombudsman. ${ }^{92}$

The Ombudsman's Office also acted when the government opted to ignore IACtHR rulings. This was the case, for instance, with the judgement granting reparations to María Elena Loayza Tamayo, but which were then declared 'unenforceable' in June 1999 by the Second Criminal Chamber of the Supreme Court. ${ }^{93}$

A third and more recent thematic area of direct action relates to local government failings, notably the refusal of Lima's metropolitan authorities to comply with rulings issued in amparo proceedings. Workers affected by this failure have, after exhausting domestic remedies, turned to the IACHR to try and solve the issue and, at the same time, have requested assistance from the Ombudsman's Office. ${ }^{94}$

\section{0-onwards: Pursuing Domestic Remedy and Internalisation}

In a newly democratic era, the Ombudsman has encountered both more ambiguity regarding state commitment to rights protections and an expanded rights panorama, which has meant engaging issues that may be less amenable to judicial resolution. Much of the Ombudsman's current work is focused on three priority areas: (1) access to justice, especially violation of due process in the sentencing of delinquents, (2) enhancing transparency within state structures, requiring investment in training of public officials and reform of internal procedures, and (3) citizen security, with an emphasis on working in collaboration with local municipal government and communities. ${ }^{95}$ The office has also established a high profile in monitoring and intervening in social conflicts. ${ }^{96}$ The Ombudsman approaches these issues through a human rights optic. However, under Vega and Merino, resolution has often been

\footnotetext{
${ }^{91}$ See Baruch Ivcher vs. Peru [2001]

92 DP report Situación de la Libertad de Expresión en el Perú / Septiembre 1996 - Septiembre 2000".

${ }^{93}$ See Loayza-Tamayo vs. Peru, November 1999 (compliance with judgment).

${ }^{94}$ See Acevedo-Jaramillo et al. v. Peru [2006]

${ }^{95}$ See Ombudsman reports and publications.

${ }^{96}$ See Defensoría del Pueblo expuso los resultados de la investigación sobre 153 conflictos sociales vinculados a los recursos hídricos, registrados entre el 2011 y el 2014, Nota de Prensa 058/OCII/DP/2015.
} 
pursued through channels other than domestic (let alone international) legal venues. That said, as Ombudsman reports make clear, complaints lodged against Peru in the IACHR by third party actors do reflect this new rights reality:

Complaints before the Commission do not only relate to the violence during 19802000; 46.5\% concerned labour rights issues, such as pensions, sackings, dismissal of judges, large redundancies etc... ${ }^{97}$

Merino and Vega's priorities appear to have been more structurally-oriented, moving the Ombudsman away from the legal role of constitutional guardian, as advanced under Santistevan and Albán. The office in recent years has had notable successes in asserting a rights-based discourse into public policy-making, often drawing on IAHRS standards in the process. For example, in a landmark report on the right to water in Peru, the Ombudsman made a compelling case for state obligations drawing on IACtHR rulings, the American Convention, among other sources. ${ }^{98}$ As one official remarks "the jurisprudence of the court, as well as commission criteria, form an important part of Peru's binding legal framework. The decisions of the system have real force, they are generally technically more solid that domestic decisions". 99

The absence of direct litigation efforts by Merino or Vega may respond to professional profiles and changing political conditions, but internal organisational factors have also played a role. It is important to acknowledge that international litigation is resource-intensive, requiring technical expertise and sustained attention over the course of the judicial process. Observers highlight that resource constraints have also factored into internal decisionmaking, "we've had budget cuts, we are overloaded with work. For example, the issue of citizen security demands roughly 60 percent of our attention across many units of the Ombudsman, this issue simply did not demand that level of attention under the first two Defensors". 100

97 Ombudsman's Office. Twelfth Annual Report. Peru, 2009.

${ }^{98}$ See Defensoría del Pueblo, Ciudadanos Sin Agua: Análisis de un derechos vulnerado, informe No. 94 (Lima: DP, 2005): 11 .

${ }^{99}$ Fernando Castañeda, Deputy Ombudsman for Constitutional Affairs (interim), Peruvian Human Rights Ombudsman, interview with Tom Pegram, 11 September 2015.

${ }^{100}$ Fernando Castañeda, 11 September 2015. 
However, it is also important to highlight that the budget of the Ombudsman in recent years has become more dependent on the government. During the tenure of Santistevan and Alban, international funding accounted for close to 70 percent of the total budget. In practice, this gave the Ombudsman something close to "absolute autonomy". ${ }^{101}$ Under Merino, this ratio was reversed, with international funding falling to 30 percent or under. Merino proved effective at negotiating budgetary increases during her period in office. However, this may have been at the cost of scaling back direct confrontation with the Garcia administration through the IAHRS. Concerns were raised at her muted stance towards certain egregious violations. ${ }^{102}$ However, it is important to note that Ombudsman representations continued, even regarding highly contentious IACtHR decisions. For example, the case of Cantoral Huamani y García Santa Cruz vs. Peru [2007] directly implicated the first administration of Garcia in the assassination of a trade union leader in 1989. The Ombudsman did seek to advance compliance with the ruling through legal channels, even if this met with little success. ${ }^{103}$

Remedy at the domestic level is rarely straightforward in Peru. However, new democratic governments have proven more responsive to domestic human rights mobilisation than Fujimori. When the Garcia government shut down a local radio station for allegedly stoking violence in the province of Bagua in 2009, Merino intervened in the media, supported by diverse social actors, to denounce the action as a violation of freedom of expression. ${ }^{104}$ The Ombudsman "stood ready to take the case to the international system." 105 However, the government relented, reinstating the radio station's licence to broadcast. ${ }^{106}$ As an Ombudsman official remarks, "this would have been inconceivable under Fujimori". ${ }^{107}$ Similarly, in a highly public confrontation between Defensor Eduardo Vega and the Humala government, the government was forced to suspend mandatory military service following a successful legal action by the Ombudsman before the Constitutional Tribunal which declared the practice discriminatory. Humala accused the Ombudsman of "endangering national security", but nevertheless complied with the ruling. ${ }^{108}$ The office currently has another legal

\footnotetext{
${ }^{101}$ Fernando Castañeda, 11 September 2015.

102 Wilfredo Ardito, Director for Economic, Social and Cultural Rights in APRODEH, interview by Tom Pegram, Lima, Peru, 10 June 2008.

103 See Defensoría del Pueblo, Oficio No. 395-2010/DP/PAD, 28 September 2010.

${ }^{104}$ La República, 'Defensoría pide al MTC suspender licitación de Radio La Voz de Bagua', 18 August 2010.

${ }^{105}$ Fernando Castañeda, 11 September 2015.

${ }^{106}$ Perú 21, 'Restituyen licencia a La Voz de Bagua', 19 August 2010.

${ }^{107}$ Fernando Castañeda, 11 September 2015.

${ }^{108}$ Gestión, Ollanta Humala insiste en que el actual servicio militar es "el discriminatorio", 18 June 2013.
} 
action pending before the Constitutional Tribunal regarding access to information. ${ }^{109}$ If the case fails, "then we will evaluate the possibility of going to the international system". 110

Legacy violations from 20 years of internal conflict continue to inform the work of the Ombudsman, particularly in its role as custodian of the legacy of the TRC. The IAHRS has played a prominent role in this domain as well. It is here that the IAHRS has provoked most controversy in Peru. As an early good will gesture under the Paniagua administration, the Peruvian state agreed to investigate 159 cases of disappearances as part of an IACHRbrokered friendly settlement entered in February 2001. ${ }^{111}$ However, implementation of this settlement has failed to deliver (Root 2013). In a report published in 2009, the Ombudsman detailed some progress, but the bulk of its findings highlighted significant cause for concern:

Of 26 cases that were transferred to the [IACtHR], 23 ended in judgments against the Peruvian state, one case was dismissed and the two others were only recently admitted. Compliance with judicial orders to pay compensation remained pending in 11 cases; with orders to investigate, prosecute and punish in 11 cases; rehabilitation measures in four cases; symbolic measures acts of atonement in six cases; and restitutive measures in eight cases. ${ }^{112}$

As noted above, the domestic political climate has become hostile, even dangerous, for human rights advocates in recent years. ${ }^{113}$ Both the Garcia and Humala administrations have provoked conflict with the IAHRS to galvanise political support for regressive human rights policies. An increasingly embattled Ombudsman has nevertheless defended the IAHRS against attack. Two high profile examples include Garcia's provocation to restore the death penalty for child sex offenders, which would have jeopardised Peru's membership of the IACHR. For his part, Humala and other actors have insinuated that the IACtHR supports terrorists. ${ }^{114}$ In both instances, the Ombudsman took to the airwaves in defence of the

\footnotetext{
${ }^{109}$ See Defensoría del Pueblo, Proceso de inconstitucionalidad, Doc. No. 05-2013-AI.

${ }^{110}$ Fernando Castañeda, 11 September 2015.

111 Ombudsman's Report No. 128, El Estado frente a las víctimas de la violencia. ¿Hacia dónde vamos en politicas de reparación y justicia?, p. 162.

112 Ombudsman's Office. Twelfth Annual Report. Peru, 2009.

${ }^{113}$ El Comercio, 'Salomón Lerner denunció que ha sido amenazado de muerte por teléfono', 24 September 2009.

${ }^{114}$ See El Comercio "No le daremos ni un sol a terrucos así lo diga la Corte IDH", 26 June 2015.
} 
IAHRS, exhorting the government to comply with its obligations under international law. ${ }^{115}$ However, the office is an increasingly isolated voice and there is disquiet regarding the inability (or unwillingness) of IAHRS officials to more actively counter misinformation campaigns either by direct intervention, or through support of the Ombudsman and other proaccountability actors on the ground. The promise of mutual support, formalised in an institutional agreement in 2010 between the IACtHR, the Peruvian Ombudsman and the Ibero-American Ombudsman Federation, is yet to be realised. ${ }^{116}$

\subsection{Means, Motive and Opportunity for Enhancing Interaction}

Even in the contested arena of legacy violations, it is important to acknowledge that the relationship between the Peruvian government and the IAHRS is multi-faceted. There has been some progress, especially on reparations, if not prosecutions, for human rights crimes (Root 2013). The state has also sought to pre-empt potential conflict with the IAHRS. For example, observers note that the retrial in 2001 of terrorism suspect, US citizen Lori Berenson, was conducted with all due process guarantees carefully observed to avoid the sentence being subsequently struck down. ${ }^{117}$ The case reached the IACtHR in 2004, with the Court upholding the conviction and sentence and Toledo welcoming the verdict. ${ }^{118}$ However, the IACtHR's recent decision in Eduardo Nicolás Cruz Sánchez (Chavín de Huántar) vs. Peru [2015] in favour of those convicted of terrorist offences have provoked powerful political opposition in Peru, as well as exposing collusion to undermine the IAHRS at the highest levels of government and the judiciary. ${ }^{119}$

The IAHRS could enhance its navigation of these complex dynamics. And the Peruvian Ombudsman is well-placed to assist in that task. As a local interlocutor, the Peruvian office is credible with a broad range of civil society actors and other pro-reform constituencies. It is also well-placed to provide guidance to the IAHRS on the domestic political ecology which informs implementation actions at the local level. A senior Ombudsman official highlights

\footnotetext{
${ }^{115}$ See Perú 21, 'Merino advierte que pena de muerte no puede someterse a referéndum', 12 January 2007; Andina, 'Defensoría destaca sentencia de CorteIDH por desaparecidos en gobierno de Fujimori', 27 November 2015.

116 See FIO y Defensoría del Pueblo de Perú suscribieron convenios con la Corte IDH, 13 April 2010.

117 Jose Alejandro Godoy, 'El Peru y la Corte Interamericana de Derechos Humanos', 10 March 2015: http://www.desdeeltercerpiso.com/2015/03/el-peru-y-la-corte-interamericana-de-derechos-humanos/

118 Perú 21, 'Toledo confirma decisión de la Corte en caso Berenson', 2 December 2004.

${ }^{119}$ See La República, 'Jiménez a la jueza: "Si podemos, en este caso, archivar...”, 5 August 2013.
} 
three main ways in which the Ombudsman can assist the Court, Commission and other system agencies in their work: ${ }^{120}$

1. System Diagnoses and Remedy: the Ombudsman can serve as a bridge between the IAHRS and the domestic jurisdiction. Enhancing knowledge of these two arenas in both directions is important. For the IAHRS, it is vital that system agents obtain an accurate picture of the internal political regime so that they can calibrate implementation efforts in light of domestic political conditions. The Ombudsman is well-placed to provide detailed insight into the specific context which gives rise to violations. Such information could enhance the precision of system resolutions and rulings.

2. Changing Public Opinion: At the domestic level, the Ombudsman can facilitate IAHRS efforts to enhance knowledge of its procedures so that diverse stakeholders, including judges, state bureaucrats, political elites and citizens, can familiarise themselves with the international machinery. The system is often criticised by vocal detractors internally for being elitist and handing down decisions which do not reflect the Peruvian reality. The Ombudsman could assist the IAHRS in improving its education and diffusion mechanisms in order to demonstrate that "the court is not for anything or anybody, rather that the court interprets the law and applies it as is appropriate". ${ }^{121}$ Indeed, one concrete proposal would be for the court to hold its sessions in-country, facilitated by the Ombudsman and other actors.

3. Specialised Information: The Ombudsman is a valuable source of information for the IAHRS, including on specialised issues such as vulnerable groups, socioenvironmental conflict, structural violations regarding social security, access to information, and a range of other rights concerns. A vast repository of information can be found in its 160 published special reports. ${ }^{122}$ This information "is impossible for the system to collect on its own and could help a lot in the elaboration of decisions". ${ }^{123}$

\footnotetext{
${ }^{120}$ Fernando Castañeda, 11 September 2015.

${ }^{121}$ Fernando Castañeda, 11 September 2015.

122 Available on website

${ }^{123}$ Fernando Castañeda, 11 September 2015.
} 


\section{Conclusion}

In light of this study, it is perhaps time for the IAHRS to more proactively engage a wider array of domestic intermediaries including NHRIs. The Peruvian Ombudsman has never received a request for assistance from the Court. This omission may be due to protocols established by the IAHRS which principally privilege the victim and the state in its procedures. With the state implicitly treated as monolithic, the Court and Commission have struggled to accommodate independent sub-state actors. Notwithstanding these constraints, this study has highlighted multiple ways in which credible NHRIs have engaged with the system and could yet further enhance its work.

The work of the IAHRS is by its nature difficult, intruding onto sovereign territory and calling powerful actors to account. The slow movement towards engaging with NHRIs in its work may well reflect reasonable fears on the part of IAHRS judges, commissioners, as well as bureaucrats, that such action will provoke backlash from their proximate political body and governmental delegations at the Organization of American States (OAS). However, given the resource constraints already imposed on the IAHRS, the benefits of more actively orchestrating activities with NHRIs may well outweigh the potential costs. It is also worth noting that the OAS has repeatedly endorsed the work of NHRIs in a series of resolutions stretching back to the mid-1990s. ${ }^{124}$ The system could do more to engage credible NHRIs in its activities, both as a resource to buttress its own impact and to provide support for its embattled supporters at the domestic level.

If the IAHRS proves unwilling to further articulate its relationship with domestic rights constituencies, it risks deepening a sense of drift and distance from the realities of human rights politics on the ground. For NHRIs, such as the Peruvian Ombudsman, the day-to-day demands placed upon it will take priority over enhancing interaction with an international system which appears reluctant to reciprocate. The IAHRS needs the support of NHRIs and other domestic interlocutors if it is to sustain its relevance and secure implementation with its decisions. It is incumbent on all parties to respond positively to opportunities for deepening engagement. As Fernando Castañeda, Deputy Ombudsman for Constitutional Affairs in Peru, puts it:

\footnotetext{
${ }^{124}$ See Support for International Exchanges Among Ombudsmen, adopted 5 June 1997, G.A. Res. 1505 (XXVII-0/97).
} 
We need a closer dialogue. We need to recognise that we are both working towards the same goal. The sentences of the Court are good, they are well-founded, its personnel are professionals of the highest calibre, and we have the same objectives. Distance must not prevent this important system of protection from making a difference on the ground... ${ }^{125}$

\section{Bibliography}

Chipoco C., 'La Defensoría del Pueblo, la defensa de los derechos humanos y la promoción de la democracia en el Sistema Interamericano', Debate Defensorial, no. 3. Lima, Defensoría del Pueblo, May 2001

Carver, Richard, Performance and Legitimacy: National Human Rights Institutions (Versoix: ICHRP, 2000).

Cavallaro, James and Erin Brewer, 'Re-evaluating Regional Human Rights Litigation in the Twenty-First Century: The Case of the Inter-American Court', The American Journal of International Law, vol. 102, no. 4, October 2008, pp. 768-827

Dulitzky, Ariel, 'The Inter-American Human Rights System Fifty Years Later: Time for Changes', Quebec Journal of International Law, no. 127, 2011

Finnemore, M., National interests in international society (Cornell University Press, 1996)

González Volio, Lorena, Los Ombudsman en América Latina y su incidencia política, 2009

IACtHR, Annual Report, 2010.

Inter-American Yearbook on Human Rights 1991: Inter-American Commission on Human Rights, Martinus Nijhoff Publishers, Jan 1, 1995

Levitsky, Steven and Mara Victoria Murillo, 'Variation in Institutional Strength,' Annual Review of Political Science, vol. 12, 2009, pp. 115-133

Méndez, Juan and Irene Aguilar, La Relación entre el Ombudsman y el Derecho Internacional de los Derechos Humanos, Memoria II Congreso Anual de la Federación Iberoamericana del Ombudsman, FIO, Madrid, 1998

O'Donnell, Guillermo, 'Horizontal Accountability in New Democracies,' Journal of Democracy, vol. 9, no. 3, 1998, p. 112-126.

Open Justice, From Rights to Remedies (Open Society Justice Initiative, 2013)

Parra Vera, Oscar Javier, 'El Sistema Interamericano y el enfoque de derechos en las estrategias de desarrollo y erradicación de la pobreza. Algunas líneas de trabajo para las Defensorías del Pueblo', Cuadernos Electrónicos De Derechos Humanos y Democracia, vol. 5, 2009, pp.83-104

Pasqualucci, J., The Practice and Procedure of the Inter-American Court of Human Rights (Cambridge University Press, 2013, $2^{\text {nd }}$ ed.)

${ }^{125}$ Fernando Castaneda, 11 September 2015. 
Pegram, Thomas, 'Accountability in Hostile Times: the Case of the Peruvian Human Rights Ombudsman 1996-2001', Journal of Latin American Studies, vol. 40, no. 1, February 2008, pp. 51-82.

Pegram, Thomas, 'Weak institutions, rights claims and pathways to compliance: the transformative role of the Peruvian Human Rights Ombudsman,' Oxford Development Studies, vol. 39(2), June 2011, 229-250.

Pegram, Thomas, 'National human rights institutions in Latin America: Politics and institutionalization,' in R. Goodman and T. Pegram (eds.), Human Rights, State Compliance, and Social Change: Assessing National Human Rights Institutions (Cambridge University Press, 2012), Ch. 9.

Pegram, Thomas, 'Global Human Rights Governance and Orchestration: National Human Rights Institutions as Intermediaries,' European Journal of International Relations, vol. 21(3), August 2015, 1-26.

Przeworski, Adam, Susan Stokes and Bernard Manin, Democracy, Accountability, and Representation, (Cambridge: University of Cambridge Press, 1999).

Reif, L., The Ombudsman, Good Governance and the International Human Rights System (Boston: Martinus Nijhoff Publishers, 2004).

Risse, T. et al., The Persistent Power of Human Rights (Cambridge University Press, 2013)

Root, R., Transitional Justice in Peru (Basingstoke: Palgrave Macmillan, 2013)

Santistevan, Jorge, 'The Ombudsman institution and accountability in societies of transition', 2000 .

Santistevan, Jorge, 'El Defensor del Pueblo en Iberoamérica', in Comisión Nacional de los Derechos Humanos, Retos actuales de las instituciones nacionales de protección y promoción de los Derechos Humanos (Mexico City D.F.: CNDH, 2004), pp. 27-106.

Simmons, B., Mobilizing for Human Rights: International Law in Domestic Politics (Cambridge, Cambridge University Press, 2009)

Slaughter, Anne-Marie, A New World Order: Government Networks and the Disaggregated State, (Princeton University Press, 2004)

Smith, Anne, 'The Unique Position of National Human Rights Institutions: A Mixed Blessing?' Human Rights Quarterly, vol. 28, 2006, pp. 904-946

United Nations Centre for Human Rights, National Human Rights Institutions: A Handbook on the Establishment and Strengthening of National Institutions for the Promotion and Protection of Human Rights, (4 UN Document HR/P/PT 4, 1995)

Youngers, Coletta, Deconstructing Democracy: Peru under President Alberto Fujimori, (Washington, D.C.: Washington Office on Latin America, 2000). 